Journal of Business Studies - JBS Vol.13 Issue.2, December 2017

\title{
COLLABORATIVE INNOVATION OF STRATEGIC EMERGING INDUSTRIES: A CASE STUDY OF THE NEW GENERATIONOF INFORMATION TECHNOLOGY ENTERPRISES IN CHINA
}

\author{
Muhammad Imran Hanif \\ Institute of Banking and Finance, Bahauddin Zakariya University, Multan, Pakistan; \\ Asif Kamran \\ ILMA University, Management Science Department. \\ Muhammad Shahzad Hanif \\ PhD, Scholar, University of Electronic Science and Technology, China; Email; \\ Yunfei Shao \\ Professor, University of Electronic Science and Technology, UESTC, Chengdu, China
}

\begin{abstract}
The new generation of information technology industry studied in this study, is constructed as the first batch of national key support industry. On the ground of the analysis of the new generation of information technology industry in China, the current main problem faced by the enterprises, is being with relatively deficient resources, that is, resources of human, finance and property can't fundamentally meet the needs of the enterprise development, especially an extraordinary lack of high level talented people urgently needed by enterprises. This paper focuses on the problems existing in the collaboration of various resources in the new generation of IT enterprises with the application of collaborative innovation and technology innovation theory on the research of elements of the enterprise innovation, trying to solve some practical problems. The contents of the research mainly center on how each innovative factors Strategic innovation, system innovation, cultural innovation, organizational innovation, technological innovation, market innovation, management innovation within the IT enterprises collaboratively innovate and explore the relationship within the innovative factors and finally construct the collaborative innovation model.
\end{abstract}

Keywords: Collaborative Innovation; Emerging Industries; Information Technology; IT Enterprises

\section{Jel Classification:C612, C615, C619}

*The material presented by the author does not necessarily portray the view point of the editors and the management of the Ilma University - Formerly IBT

1. Muhammad Imran Hanif: mimranhanif@bzu.edu.pk

2. Asif Kamran: asifkamrankhan@gmail.com

3. Muhammad Shahzad Hanif: mshahzadhanif@yahoo.com

4. Yunfei Shao: shaoyf@uestc.edu.cn

CILMA-JBS is published by the Ilma University - Formerly IBT

Main Ibrahim Hydri Road, Korangi Creek, Karachi-75190, Pakistan. 


\section{INTRODUCTION}

In the $21^{\text {st }}$ century, the global economic environment has experienced enormous changes. The traditional development modes of Information Technology Enterprises are hard to go on.

Their foreign counterparts as well as encounter face many challenges and difficulties in selection of opportunities, decision making and construction.

The new generation of information technology industry studied in this study, is constructed as the first batch of national key support industry. On the ground of the analysis of the new generation of information technology industry in our country, the current main problem faced by the enterprises, is being with relatively deficient resources, that is, resources of human, finance and property can't fundamentally meet the needs of the enterprise development, especially an extraordinary lack of high level talented people urgently needed by enterprises. Financially, corporate debt ratio is high and operating funds are nervous. Environmentally, the office, business and equipment, buildings are hard to be guaranteed. What's more, the Enterprise management mode is extensive with weak basic management and relatively high cost of operating management. The enterprises also lack flexible quickly reflect market mechanism or strong control of market. This paper focuses on the problems existing in the collaboration of various resources in the new generation of IT enterprises with the application of collaborative innovation and technology innovation theory on the research of elements of the enterprise innovation, trying to solve some practical problems.

In recent years, scholars have explored collaborative innovation and made some achievement, providing an important theoretical basis to more research for innovative practice. Based on the existing literature, the thesis makes deep analysis of the internal elements of the collaborative innovation in the new generation of information technology enterprises to enhance their core competitiveness. The collaborative innovation in the text refers to the cooperation among the internal innovative elements in the new generation of IT enterprises, which leads to the improvement of innovation performance within the enterprises, thus enhancing their innovation ability. This paper primarily focuses on the three aspects below: 1.The influencing factors in the innovation activity 2 . The construction and verification of the collaborative innovation model 3. The application of the model is solve the pragmatic problems. The contents of the research mainly center on how each innovative factors Strategic innovation, system innovation, cultural innovation, organizational innovation, technological innovation, market innovation, management innovation within the IT enterprises collaboratively innovate and explore the relationship within the innovative factors and finally construct the collaborative innovation model.

\section{LITERATURE REVIEW}

With the fierce market competition, enterprises began to pay attention to the importance of collaborative innovation. Scholars began to study how innovative factors promote synergistic blend of innovation and improve the innovation performance of enterprises, trying to bring a new awareness that the innovation is a whole system. Collaborative associations through combined research, consulting or training preparations are most essential communication networks for the industry than patents, and licenses Cohen et al. 2002. Many researches have done in past literature on the influence of industry collaboration Agrawal and Henderson (2002), Thursby and Thursby, (2007). Consequently, the costs and benefits of collaborative developments vary conditional on the institutional 
culture Owen-Smith and Powell, 2001; Levin and Stephan, 1991 and later it may then lead to variance influence of industry collaboration on publication outputs. The research on innovation networks highpoints the advantages of these networks to technology-based firms Rothaermal et al.(2007). Moreover, the mainstream of studies distillate either on large firms with developed R\&D actions e.g. Fabrizio (2006) or spin-offs from university Grandi \& Grimaldi (2003); Johansson, Jacob \& Hellström (2005); Pérez \& Sánchez (2003). This argument is in direction with the theory of knowledge- based which stressed that industries and their collaboration designs differ based on leading styles of knowledge (Asheim 2007; Asheim \& Gertler 2005; Asheim et al. 2007).

In recent years, some Chinese academics and scholars have explored the synergy from philosophy, sociology, economics and management science perspective. Zhang Gang, Chen Jin and Qingrui 1997 have studied in depth about enterprise technology, organization and culture of collaboration and depicted that technology plays integral part in the development of enterprises. Guo Bin and Qingrui (1997) have explored the behavior of collaborative innovation and explained that the collaborative innovation is very important for organizations and pointed out many technical constraints . (Zhang Gang and Chen Jin;1997) highlighted that in collaborative innovation model, firm have worked on many technical, organizational and cultural factors as key sources and issues of innovation development. Zhuzu Ping; (1998) has studied different organizations, and indicated that culture, strategy, product and process have serious impact on business innovation. Peng Yi (1999) worked on the micro-level study of collaborative enterprises operational mechanism between "Competition - coordination cooperation" . Peng Jisheng 2000 through the process of technological innovation research , analyzed its innovative features and the establishment of relevant mathematical models. Zhang Zong and Qing (2000) studied the technical innovation stage analysis. Furthermore, their research work highlighted a key role of corporate knowledge, systems and organizations in promoting technological innovation. Shen Xiaoping and Sun Dongchuan (2001) have studied many Chinese companies and their close linkage between enterprise technology and management.

They suggested future research by exploring this relation in building enterprise collaborative innovation model for future research and for management of collaborative technologies providing the foundation. Liu Jin and Yang Jiping 2002 said that from the perspective of economics and management to build a cluster of game model enterprise collaboration . Wang Fangrui (2003) built a dynamic model on the market through innovation and technology collaborative research . Zheng Gang (2004) worked on a comprehensive and innovative collaborative research enterprise technology innovation perspective of the elements of the process. They further explored the establishment of collaborative business model innovation elements. They expressed that the use of specific cases to verify the collaborative model. SOCIALIST (2005) made a comparative analysis of technological innovation, system innovation and industrial innovation similarities. He studied the differences while pointing out technical and institutional innovation is the driving force of the industry. Chen Jin and Wang Fangrui 2006 worked on the basis of the previous analysis of the dynamic model and find out that each element of the collaborative nature of collaborative innovation is collaborative management environment and processes.

Zheng Gang and Zhu Ling (2008) worked on the Haier Group Product Innovation Project for the case of several key factors of technological innovation process to be analyzed, and finally validated the theory by case . Bi Kexin, Sun Flower 2010 used panel data from 2000 to 2008 manufacturing enterprise technology activities and established a coordination degree model of product innovation and process innovation collaborative development Discoveries in 2008 
and concluded that China's manufacturing product innovation and process degree of innovation and collaborative development is not very high. Luke Bin and Guo Wei (2010) worked on Shaanxi textile industry and revealed the existence of the diffusion of technological innovation and industrial cluster knowledge of significant synergistic relationship. Wu occasion, Shi Chunsheng and Ming-Xia Liu 2011 established that enterprise was born and later grew on mature stages of organizational innovation and transformation elements and elements of collaborative model of technological innovation. They conducted a survey by circulating a questionnaires to 129 companies to validate the theoretical model. Zhang Xue and Zhang $\mathrm{Pu}$ (2012), expressed their work on knowledge creation area and identified that knowledge creation is integral for business activities with clients and in building a collaborative product input-output elements. Their work is an example of a business model for the establishment of input-output analysis, model deduction mechanism demo model. Feng Bo and FAN Zhi-ping (2012) studied the role of partner selection in knowledge innovation team focused on considering the synergies between the partners

\section{THE MODEL BUILDING AND RELATED ASSUMPTIONS}

Some scholars pointed out that the enterprise units within the hierarchy, the research object is mainly the function of all levels within the enterprise, Baum (2002) mainly studying the internal synergy between the elements of all levels. So the hierarchy analysis was carried out on the internal innovation elements, it was further analyzed at all levels within the enterprise, the collaborative relationship between for building a new generation of information technology enterprise synergy innovation model to provide more methods. Engel Herbert (1992) through to the enterprise level to study and put forward enterprise level point of view. The most obvious hierarchy within the enterprise is the first layer is the system, mainly including internal research and development, production, sales and after-sales service system, the process of mainly arrangements and guidance to the first layer of the work.

The second layer is mainly responsible for enterprise product research and development, manufacture and sales links, most of the resources and the enterprise internal staff are gathered in this link. The third layer is the major is the environment of an enterprise level, is the least obvious but had the greatest influence to enterprise's first two layers, it affects the enterprise internal employee ideas and impact on the development of the enterprise. Only the three levels of good together to promote enterprise development and progress.

Developing technologies permit new magnitudes of collaboration, concerning not only the arrangement on common objectives and the regular conversation of information, but also the conjoint performance of activities to comprehend innovation (Serrano, Fischer, 2007). The procedure of collaborative innovation is rather parallel to an internal innovation process accomplished within a single company (Verworn, Herstatt; 2002, or Cooper, 2008).Today innovation desires to emphasis on attractive product/process or services, produced through the rational usage of knowledge, to retain companies competitive. The empowerment is both technical and organizational on each stage of the Product Life Cycle (Mevellec, 2006).

Scholars found in the study of total factor, the effect of the elements in the process of collaborative work also is not equal, there is obvious hierarchy between elements, in order to further study on how a new generation of information technology enterprise internal elements of synergy, draw lessons from Engel Burt thought, studied factors can be divided into three levels, thus obtained in this paper, the concept of the model .This model mainly analyzes two basic questions: 
1 A new generation of information technology enterprise which elements exist collaborative innovation effect.

2 A new generation of information technology for collaborative innovation between internal elements is how the Management includes the organizational innovation and management innovation.

Management is the enterprise internal contact the operational layer and output layer, layer through the operational and performance management together, so as to improve enterprise innovation performance. The operational layer includes strategic innovation, technology innovation, market innovation and system innovation. System based on the enterprise internal value chain analysis, the main purpose is through the interconnected between enterprises strategy, technology, market and system innovation to achieve the innovation performance of the enterprise, enterprise strategy, technology, market and system innovation in the enterprise interior is clear. Cultural, mainly includes innovation culture. Corporate culture affects the enterprise internal staff working environment, thus affecting the enterprise innovation performance

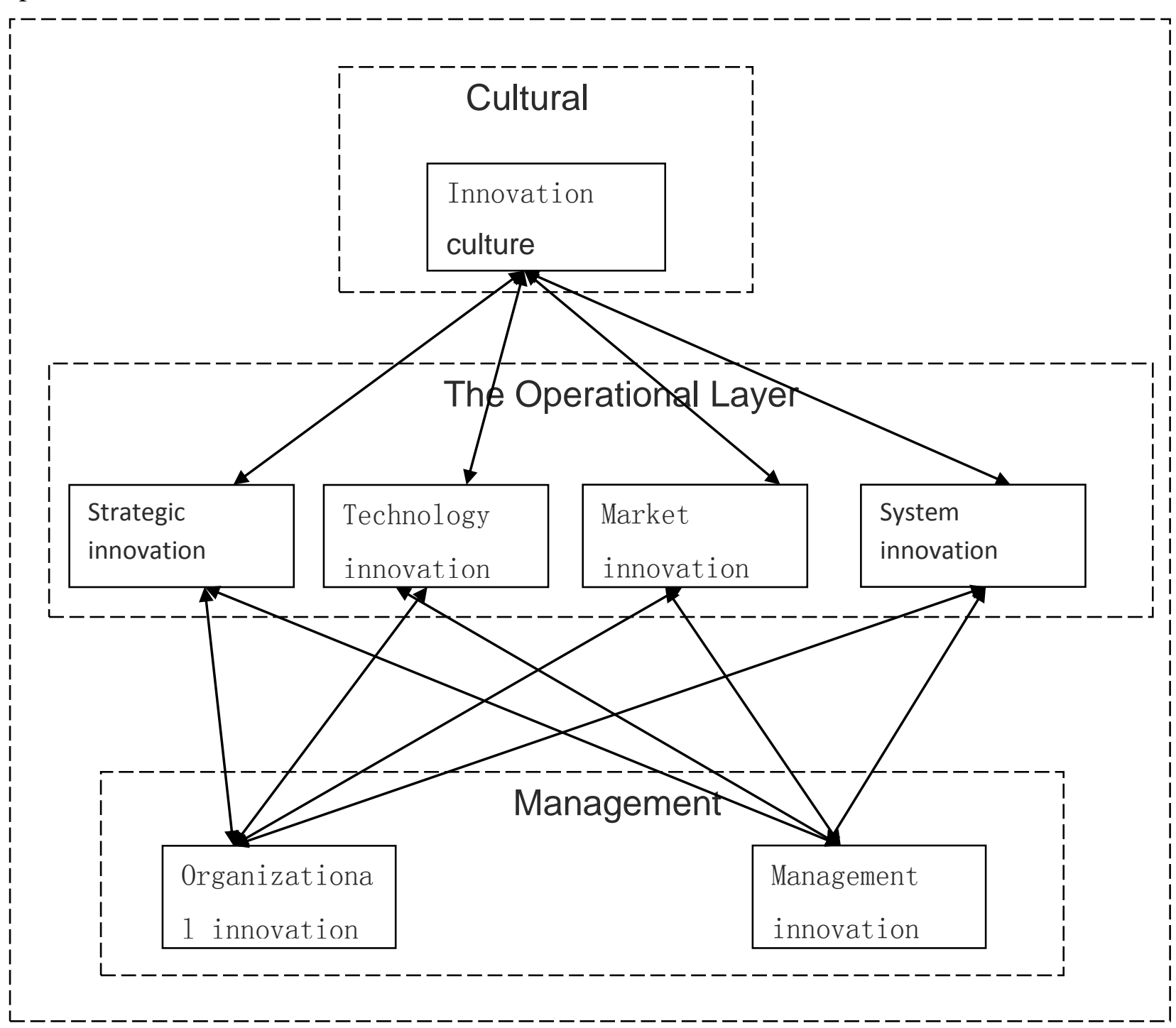

Figure .1: New Generation Information Technology Enterprise Collaborative Model 


\section{EMPIRICAL ANALYSIS MODEL}

\subsection{Data Collection}

The investigation object of this study is a new generation of information technology enterprise, according to the characteristics of the research object, using small-scale questionnaire survey, combined with the enterprise interviews for data collection activities. However, in order to improve the authenticity of the information received research, interviews with those affected by the degree of understanding and culture related. To the questionnaire survey to obtain the real situation, the survey questionnaire during the process of issuing the identities of respondents and length of service, to increase the rationality of the questionnaire investigation. The purpose of the survey is to know the influence of a new generation of information technology enterprise cooperative innovation synergy between the status quo and elements of the situation, the influence mechanism. As a new generation of information technology enterprises to further establish collaborative innovation model to provide information, can effectively enhance the innovation efficiency of the enterprise. The design of the questionnaire on the basis of the mature at home and abroad and referring to the questionnaire, in order to more accurately get real information within the enterprise, and considering the background factors such as respondents, as far as possible in the process of the design of the questionnaire in a comprehensible, and reduce the trouble people fill in the questionnaire, to save time.

The study of the questionnaire design starts from February 2012, after many team discussion and modification, determines the final version of the questionnaire, large-scale distributed in March, in June of the questionnaires were collected for analysis. The design of the questionnaire prepared in order to obtain more information, first please discussed within the team and try to fill in, some of the questionnaire easy to produce the ambiguity problem were modified, and finally to form the final draft of the questionnaire. In order to improve the recovery rate of the questionnaire, the questionnaire by mail, there is no feedback questionnaire about within one week of the enterprise, the secondary contact by phone or EMAIL, SPSS analysis was carried out on the recovery of questionnaire, the data is descriptive statistics and principal component analysis.

The survey, 1100 questionnaires were issued, recycling, 859, the total recovery rate $78.09 \%$ as shown in table 3 .

Table .3: Questionnaire Sent to Recycling

\begin{tabular}{|l|l|l|l|}
\hline \multicolumn{1}{|c|}{ Name } & $\begin{array}{l}\text { No of } \\
\text { Questionnaires }\end{array}$ & Recycling & Recycle ratio \\
\hline A large company & 400 & 323 & $80.75 \%$ \\
\hline Medium-sized companies & 400 & 298 & $74.5 \%$ \\
\hline A small company & 300 & 238 & $79.33 \%$ \\
\hline
\end{tabular}

Through the inspection of recycling questionnaire, found that part of the questionnaire on the fill out obvious problems, these questionnaire belongs to waste volume, not included in the questionnaire statistics, no recycling questionnaire 241, 859 effective questionnaires were finally. Through the analysis of data, to organize the original questionnaire. 


\subsection{Data Descriptive Statistics}

Can be seen from the chart 2, to participate in the survey of more than $81 \%$ are $31-40$ employees, these employees in the company's time for a long time, has certain understanding to the enterprise situation, $13 \%$ were 41 to 50 years old, the general is the top of the company, with $4 \%$ of people are under the age of 30 , most of these is the new company's new employees, $2 \%$ of employees is 51 to 60 years old.

Under the age of 30

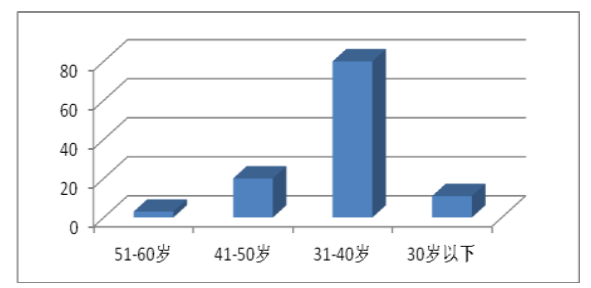

Figure .2: Employees Age Structure

Can be seen from the figure 3 below, to participate in the study of employees in more than half were undergraduate students, they know a lot about the company, the question is very objective, have very good improve the truthfulness of questionnaire investigation, the company has a few high school students, mainly in the service of answering the telephone, graduate students are mainly with the technological and data support.

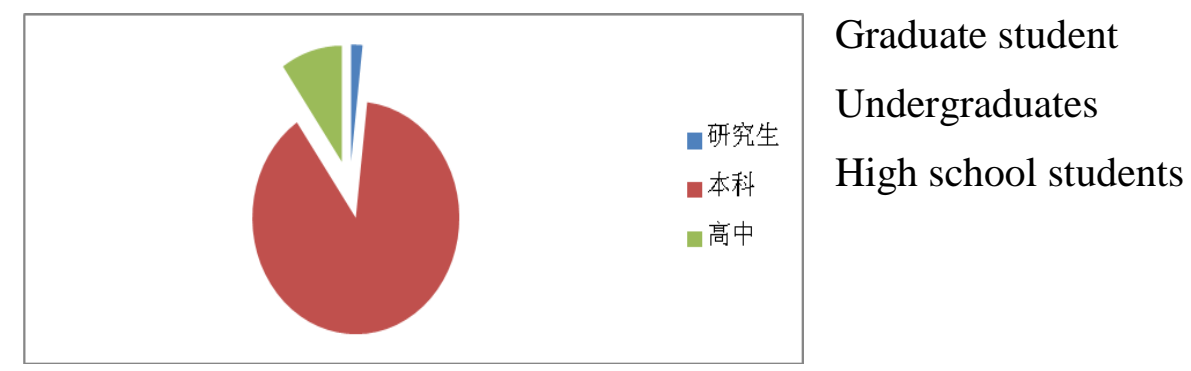

Figure .3: Employees’ Education Level

Can be seen from the figure 4, grassroots employees accounted for $46 \%$, middle employees accounted for $45 \%$, senior staff accounted for $9 \%$, this research is mainly by understanding grass-roots staff's role in the process of enterprise innovation, employees at the grass-roots level is the main force of enterprise innovation and motivation, innovation can not only rely on middle-level personnel, must also rely on the grass-roots staff in every new and improved measures are put forward in the process of production and research and development and innovation in a new way.

Series 1, senior employees, $9 \%$ and $9 \%$

Series 1, people in the middle, $45 \%$ and $45 \%$

Series 1: employees at the grass-roots level, $46 \%, 46$ 


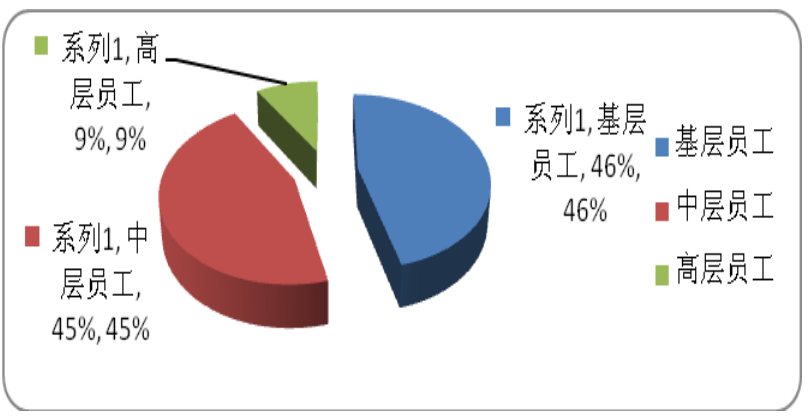

Figure. 4: Staff Position

\subsection{Variable of the Reliability and Validity Test}

Between do factor analysis, to examine the correlation between variables, the results such as shown in table 4, the variable of KMO value is 0.8590 .6 or higher, and Baetlett value of 5272.227, significant for 0.00 , can be seen from the above three data variables in this paper is suitable for factor analysis.

Table. 4: KMO and Bartlett's Test

\begin{tabular}{|l|l|}
\hline Table 4 KMO and Bartlett's test in this paper & .859 \\
\hline Bartlett sphericity of approximate chi-square test & 2572.227 \\
\hline Sig. & .000 \\
\hline
\end{tabular}

Can be seen from the table below 5 variables in this paper, the reliability of the test value is very high, the innovation performance of alpha coefficient is 0.8430 .6 or higher, alpha coefficient is 0.9130 .6 or higher of market innovation, organizational innovation of alpha coefficient is 0.8080 .6 or higher, alpha coefficient is 0.8730 .6 or higher of system innovation, strategic innovation of alpha coefficient is 0.8680 .6 or higher, technology innovation of alpha coefficient is $0.848,0.6$ or higher, the management innovation of alpha coefficient is 0.8680 .6 or higher, innovation culture of alpha coefficient is 0.8580 .6 or higher. In this paper, the main eight variables are passed the reliability test, and explain the questionnaire to fill in the situation is very good.

\subsection{Factor Analysis of Four Variables}

First, the survey data for factor analysis, the results are shown in Table $6 \mathrm{~N}=2389$ shows. According to the results of the factor analysis can be seen in this total extracted eight principal components, which explain the total variable reaches $66.804 \%$. One of the main components of an innovation performance primarily by A1, A2, A3, A4 consists of four factors; main component two market innovation is dominated by A7, A8, A9 composed of three factors; principal component is dominated by three organizational innovation A10, A11, A12 noon three factors form; main ingredient four institutional innovation is dominated by A15, A17, A18, A19, A20 composed of five factors; principal component five strategic innovation is dominated by A21, A22, A23, A24, A25 composed of five factors; main ingredient six technological innovation by A26, A28, A29, A30 these four factors form; main ingredient seven main ingredient eight innovation management innovation performance by the A36, A37, A38, A39 these four factors components. The A5, A6, A16, A27, A31, A40, 
A41 because it does not fall within the above eight main ingredients, so be deleted and Eight ingredients have extracted.

\subsection{Test Results}

According to the results of the factor analysis section above come through structural equation model of the article in front of the model validation. First test the internal culture of innovation and enterprise strategy innovation, technological innovation, system innovation, market innovation, management innovation and organizational innovation if there is a synergistic relationship, shown in Figure 5

Figure 5 culture of innovation and the management and operation of layer collaborative model M0. As it can be seen from Figure 5, the model M0 relationship between the elements of the internal model TLI is 0.901 , CFI 0.906 have passed the test. Figure 5 can be derived from a culture of innovation and strategic innovation is the negative impact of the technological innovation and institutional innovation, market innovation, management innovation and organizational innovation is positively affected.

Table .7: Model Fitness Results

\begin{tabular}{|l|l|l|}
\hline Model Fitting results & Statistics & Reference \\
\hline $\mathrm{x} 2$ & 754.519 & $\mathrm{n} / \mathrm{a}$ \\
\hline Df & 344 & $\mathrm{n} / \mathrm{a}$ \\
\hline $\mathrm{x} 2 / \mathrm{df}$ & 2.193 & $<3.0$ \\
\hline TLI & 0.901 & $\geq 0.9$ \\
\hline CFI & 0.906 & $\geq 0.9$ \\
\hline RMSEA & 0.076 & $\leq 0.08$ \\
\hline
\end{tabular}

Fitting results can be seen from Table 8, a culture of innovation and strategic innovation is negatively affecting its coefficient is -0.432 , and the impact of technological innovation coefficient is 0.122 , and system innovation impact factor is 0.381 , and the impact factor is market innovation 0.263, and management innovation impact factor is 0.154 , and organizational innovation impact factor is 0.192. Description culture of innovation and technological innovation, system innovation, market innovation culture and enterprise system innovation, market innovation, technological innovation, management innovation and organizational innovation there is a positive synergy. Synergies management innovation and organizational innovation is there to prove the hypothesis presented in this paper, that paper internal innovation.

\section{CONCLUSIONS AND FUTURE RECOMMENDATIONS}

In the fourth section of this article to verify the assumption that the third part of the validation results are; verify that the corporate culture of innovation and technological innovation, system innovation, market innovation, management innovation, organizational innovation has a positive synergy from the fourth part of the test can be seen that a culture of innovation and strategic innovation is the influence coefficient is -0.432 , that does not generate synergies between innovation and strategic innovation culture, and the fundamental reason is the new generation of information technology companies are currently in the process of transformation, strategic innovation guiding role of innovation performance is not well reflected, but as a constraint to innovation factor in performance. Now a new generation 
of information technology innovation strategy of enterprises has shifted, started by the previous defensive strategy into an offensive strategy, now the main goal is to enhance the company's market share, due to the new generation of information technology enterprise strategy to prepare preliminary work is not done, but corporate culture on the implementation of the strategy has played a negative role.

Through the above research findings validate the new generation of IT synergies between the internal elements of the preceding six validate assumptions made, five assumption has been verified. Therefore, in the development stage should pay attention to corporate culture synergy with other elements, made the following recommendations based on this:

1. Normative Regulate Management Attention to the Management: A new generation of IT companies should standardize their management innovation system, so as to improve the company's efficiency, fewer errors reduce costs, create awareness among employees. Should therefore focus on the next generation of information technology within the enterprise execution management. The final step is to strengthen the corporate culture flexible and management rigid coordination, publicity and management of corporate culture. The new generation IT enterprises should regulate the management innovation system in order to improve efficiency, reduce error cost and foster staff's cooperation awareness. Thus, it's necessary to pay high attention to the strengthen internal execution management. Besides, it should be noted that the coordination between culture and administration should be strengthened, that is, the propaganda of enterprise culture and management.

2. Importance to the Internal Learning and Communication: In today's competitive society, the new generation IT companies must have their own core competence to survive in such fierce competition environment, which is embodied as the technological innovation capability of enterprises. Many scholars have also proved that enterprise culture promotes the innovation capability of enterprises by research.

3. Inspire Staff Enthusiasm Motivate Employees' Working Enthusiasm: First, employees must recognize the company's vision, let employees know the company's development goals, by making the employees with the company's target goal of consistent corporate culture. Secondly, through the promotion of enterprise culture, establish a vision of individual employees, executives should approach communicate with employees.

Firstly, make employees aware of the business vision as well as development goals. Secondly, the propaganda of the corporation culture and the communication with leaders help employees own their vision.

4. Perform Social Duties: The new generation IT enterprises should actively perform their social responsibilities for the sake of raising social image and fame, thus reducing publicity expenses and win customers and the whole society's support and identification. Meanwhile, this help enroll excellent workers and improve employee's loyalty and performance.

5. Internal Study and Communication: Enhancing study and communication among employees is an important way to improve communication and develop technology innovation. Such as holding activities among department which brainstorm new ideas and stimulate further development.

6. Improve Staff Loyalty: Loyalty of staff can be improved by boosting their self-satisfaction through organization innovation, mutual coordination as well as harmonious working environment and interpersonal relationship. Furthermore, establishing fair compensation 
system, training mechanism, and promotion mechanism. Enterprises should give employees challenging work and stimulate the potential.

7. Occupy the Customer-Oriented Market: To meet the current requirement of customers, enterprises should make market innovation, provide new product \&service. Besides, enterprises are advised to do refinement marketing based on the existing customer's resource, enhancing their images and competitiveness to occupy new market.

\section{REFERENCES}

Asheim BT. (2007). Regional environment for innovation and entrepreneurship, in Potter J and Miranda G eds Entrepreneurship and Local Innovation Systems in Cantabria, Spain, pp.109-130, Organization for Economic Cooperation and Development, Paris.

Asheim BT and Gertler MS. (2005). The geography of innovation: Regional innovation systems, in Fagerberg J, Mowery D and Nelson R eds The Oxford Handbook of Innovation, pp.291-317, Oxford University Press, Oxford.

Bi Kexin, Sun flower.( 2010). Based manufacturing process innovation, product innovation and coordination of the complex system of collaborative development model empirical research (J). China Soft Science, Vol. 9, pp.156- 162.

Clark, K., Fujimoto, T. (1991). Product Development Performance; Strategy, Organization, and Management in the World Auto Industry. Harvard Business School Press, Boston, pp.409-411.

Cooper. (1979). The Dimensions of Industrial New Product Success and Failure (J). Journal of Marketing, Vol.3, pp. 93-10

Chen Jin , Wang Fangrui .( 2006). Chinese enterprise technology and market a collaborative innovation mechanism based on the "Environmental Management an innovative one uncertainty" variable correlation analysis (J) Science Research, , Vol.24 (4) : 629 - . 634.

Eisenhardt, Kathleen M. Galunic. (2000). D. Coevolving Harvard Business Review Vol. 78 Issue 1,pp. 91-100.

Fabrizio KR.(2006). The use of university research in firm innovation, in Chesbrough H, Vanhaverbeke $\mathrm{W}$ and West $\mathbf{J}$ eds Open Innovation: Researching a New Paradigm, pp.134- 160, Oxford University Press, Oxford.

Feng Bo , FAN Zhi-ping.( 2012). Based on knowledge innovation team synergy partner selection method (J). Journal of Management, Vol.2, pp.258 -261.

Grandi A and Grimaldi R. (2003). Exploring the networking characteristics of new venture founding teams, Small Business Economics .Vol.21, pp. 329-341.

Guo Bin , Qingrui.( 1997). Combination of innovative research and other enterprises (J) Scientific Research, Vol.15,No. 1 ,pp.12-18.

Hong.( 2000). Multicultural minds: A dynamic constructivist approach to culture and cognition (J) American Psychologist, Vol. 7, pp.709-720.

Janszen F.(2000). The age of innovation: Making business creativity a competence, not acoincidence (M) New Jersey, Prentice Hall,

Jiang Hui, Chen Jin.(2000). Integrated innovation: a new class of innovative models (J), Research Management, Vol.21 No. 5, pp.31-39 .

Joe Tidd, John Bessant, Keith Pavitt.(1997).Managing innovation: integrating technological, market and organizational change (M) Chichester; New York:.. John Wiley.

Liu Friends of Kim, Yang Jiping .(2002).Cluster enterprise collaboration Competition Innovation Behavior Game Analysis (J). Systems Engineering, Vol. 6, pp.22- 26. 
Luke Bin Guo Wei study ( 21 ) . (2010). Industrial cluster innovation and knowledge market synergies (J). Research management, Vol. 5 ,pp.35 -43 .

Mevellec, P., Perry, N. (2006). Whole Life Cycle Cost: a new approach, International Journal of Product Lifecycle Management, vol .2, ISSN Online 1743-5129 - ISSN Print 17435110.

Peng Jisheng.( 2000). China Technology Innovation Collaborative research (D) Beijing: China Economic Publishing House,

Peng Yi ,(1999) a single tear source of new business management model - Collaborative Management (J) Central South University of Technology, Vol.3, pp. 211 -215 .

Rothaermal F, Agung SD and Jiang L. (2007). University Entrepreneurship: a Taxonomy of the Literature, Industrial and Corporate Change Vol.164, pp. 691-791.

Serrano, V., Fischer, T. (2007) .Collaborative Innovation in Ubiquitous Systems. Journal of Intelligent Manufacturing, Vol. 18, p. 599-615.

Slaw Radosevic. (1998). Defining systems of innovation: A methodological discussion (J) Technology in Society, Vol.20, No.1, pp.75-86.

SOCIALIST. (2005). technological innovation, system innovation and industrial innovation analysis (J), Contemporary Economic Research, Vol. 8, pp.31- 34.

Study (13) Shen Xiaoping, 孙东川.( 2001).Technology Innovation and Management Innovation in interactive mode ( $\mathrm{J}$ ) Science of Science and Management, Vol. 10,pp. 74-76.

Tozzoli ,Zhu Zuping .( 1998). Virtual Enterprise Quality Management Features (J). Chinese Industrial Economy, Vol. 2, pp.70 -72 .

Tucker R B. (2002).Driving growth through innovation (M) SanFrancisco:. Berrett-Koehler Pub.

Tushman, Michael L and OReilly III, Charles A. Ambidextrous organizations: Managingevolutionary and revolutionary change (J) California Management Review, Summer96 Vol.38 Issue.4:,pp.8-23.

Verworn, B., Herstatt, C. (2002). The innovation process: an introduction to process models. Working Paper No. 12, TU Harburg, 2002. Obtained through the Internet: http://www.tu-harburg.de/tim/downloads/arbeitspapiere/Working_Paper_12.pdf, accessed 25.

Wang Fangrui,( 2003). Based on collaborative innovation management research (D) enterprise technology innovation and market innovative comprehensive innovation management. Zhejiang University.

Wheelwright, S.(1992). Creating project plans to focus product development (J) Harvard Business Review, Vol. 70( 2): 70-82.

Wu occasion, Shi Chunsheng, Ming-Xia Liu .( 2011).Research (J) elements of organizational innovation and technology -based innovation elements collaborative model of enterprise life cycle . Management Engineering, Vol. 4, pp.129- 135.

Zhang Gang, Chen Jin , etc.( 1997). Collaborative innovation model technology, organization and culture (J). Scientific research,Vol.1,No. 5, pp.56 -61 .

Zhang Gang, Chen Jin and Qingrui . (1997). Collaborative innovation model technical, organizational and cultural studies (6) (J). Scientific Studies, Vol. 1, pp.12 -15 .

Zhang Xue , Zhang Pu . (2012).Collaborative product innovation and customer knowledge creation under the perspective of input-output studies $(\mathrm{J})$. Research management, Vol. 2 ,pp. 122- 129.

Zhangzong Qing . (2000). Lack of technological innovation path dependency (J). Chinese Industrial Economy, pp.1274 -1276. 
Zheng Gang, Zhu Ling.(2008). Comprehensive collaborative innovation: a five- stage comprehensive collaborative process model - a case study based Haier Group (J) Management Engineering, Vol.2,pp.24 -30 .

Zheng Gang.( 2004). TIM -based technology innovation in collaboration with the perspective of the elements of a comprehensive mechanism of (D). Zhejiang University dissertation. 
Appendix

Table .1: Enterprise Collaborative Innovation Index System

\begin{tabular}{|c|c|c|c|}
\hline Index & \multicolumn{3}{|c|}{ Indicators } \\
\hline 指标类型 & $\begin{array}{l}\text { Vari } \\
\text { able }\end{array}$ & Indicator & References \\
\hline \multirow{5}{*}{$\begin{array}{l}\text { Market } \\
\text { innovation }\end{array}$} & A5 & Strong brand building ability & Cooper1979 \\
\hline & A6 & Good cooperation with leading customers & Moenaert 1990 \\
\hline & A7 & Good master of customers's requirement & Kim \& oh $2002^{(36)}$ \\
\hline & A8 & Accurate prediction of future market & $\begin{array}{l}\text { Leenders\&Wierenga2 } \\
008\end{array}$ \\
\hline & A9 & $\begin{array}{l}\text { Ability of setting up business model in } \\
\text { marketing department }\end{array}$ & Zhang Huasheng1999 \\
\hline \multirow{5}{*}{$\begin{array}{l}\text { Organizati } \\
\text { onal } \\
\text { innovation }\end{array}$} & A10 & $\begin{array}{l}\text { Communication of Information and knowledge } \\
\text { between different departments promotes } \\
\text { collaborative innovation }\end{array}$ & 潘开灵2006 \\
\hline & A11 & High attention from senior leaders & 陈劲2007 \\
\hline & A12 & $\begin{array}{l}\text { Flexibility helps innovative organizational } \\
\text { structure }\end{array}$ & Thomke1998 \\
\hline & A13 & $\begin{array}{l}\text { Application of information and communication } \\
\text { technology }\end{array}$ & Garayannis1999 \\
\hline & A14 & Establishment of market-oriented culture & $\begin{array}{l}\text { Garcia-Moralesa } \\
\text { al2007 }\end{array}$ \\
\hline \multirow{6}{*}{$\begin{array}{l}\text { Institution } \\
\text { al } \\
\text { innovation }\end{array}$} & A15 & $\begin{array}{l}\text { Establish learning and training system } \\
\text { encouraging innovation }\end{array}$ & Ballot2001 \\
\hline & A16 & Extensive and widely shared organization flow & 郝斌任浩2008 \\
\hline & A17 & Full empowerment of staff's innovation & 潘开灵2006 \\
\hline & A18 & $\begin{array}{l}\text { Establishment of organizational platform to } \\
\text { promote sharing knowledge and information } \\
\text { among staff. }\end{array}$ & Kahn1996 \\
\hline & A19 & Provide resource support for innovation & Shipton 2000 \\
\hline & A20 & Encourage innovation & $\begin{array}{l}\text { Bharadwaj、Menon2 } \\
000\end{array}$ \\
\hline \multirow[t]{5}{*}{$\begin{array}{l}\text { Strategic } \\
\text { innovation }\end{array}$} & $\mathrm{A} 21$ & $\begin{array}{l}\text { Corporate executives have dedicated staff } \\
\text { responsible for the development and } \\
\text { implementation of innovative strategies }\end{array}$ & 郑刚2004 \\
\hline & A22 & $\begin{array}{l}\text { Corporate executives clearly the extent of } \\
\text { innovation strategy }\end{array}$ & $\begin{array}{l}\text { Drnevich\&Kriaueiun } \\
\text { as2011 }\end{array}$ \\
\hline & A23 & $\begin{array}{l}\text { The company's vision and excellent design } \\
\text { continuous improvement }\end{array}$ & 余江2005 \\
\hline & $\mathrm{A} 24$ & Corporate investment in high-tech efforts & 宝贡敏2006 \\
\hline & $\mathrm{A} 25$ & $\begin{array}{l}\text { Strategic change in favor of the ability to play a } \\
\text { central }\end{array}$ & 张宏云2007 \\
\hline \multirow[b]{2}{*}{$\begin{array}{l}\text { Technolog } \\
\mathrm{y}\end{array}$} & A26 & $\begin{array}{l}\text { Matching degree of process innovation and } \\
\text { product innovation }\end{array}$ & Ford 1996 \\
\hline & A27 & $\begin{array}{l}\text { Regular joint meetings to coordinate the } \\
\text { interests between the various departments, so as }\end{array}$ & Mumford2000 \\
\hline
\end{tabular}


Journal of Business Studies - JBS Vol.13 Issue.2, December 2017

\begin{tabular}{|c|c|c|c|}
\hline \multirow[t]{4}{*}{ innovation } & & $\begin{array}{l}\text { to ensure the normal development of efficient } \\
\text { new product }\end{array}$ & \\
\hline & A28 & $\begin{array}{l}\text { Company executives have dedicated leadership } \\
\text { among technology and other non-technical } \\
\text { coordination of departments }\end{array}$ & A K Gupta1985 \\
\hline & A29 & $\begin{array}{l}\text { Technological innovation activities have a } \\
\text { special committee to conduct cross-functional } \\
\text { decision-making advisory }\end{array}$ & Kahn1996 \\
\hline & A30 & $\begin{array}{l}\text { The current business has a clear and rational } \\
\text { technological innovation strategy }\end{array}$ & Bharadwaj2000 \\
\hline \multirow[t]{5}{*}{$\begin{array}{l}\text { Culture } \\
\text { innovation }\end{array}$} & A31 & $\begin{array}{l}\text { Use of corporate internal network to } \\
\text { communicate with colleagues more efficiently } \\
\text { to provide innovative learning reached }\end{array}$ & Scott \& Bruce1994 \\
\hline & A32 & $\begin{array}{l}\text { Collective enterprises to encourage and support } \\
\text { innovation more staff involvement }\end{array}$ & Ekvall1996 \\
\hline & A33 & $\begin{array}{l}\text { To fully cooperate to promote innovation among } \\
\text { employees }\end{array}$ & West \& Richter 2007 \\
\hline & A34 & $\begin{array}{l}\text { Employees in the enterprise can give full play to } \\
\text { their strengths to promote innovation }\end{array}$ & 郑建君2009 \\
\hline & A35 & $\begin{array}{l}\text { Corporate strategy, culture, organizational, } \\
\text { technical, marketing, systems and management } \\
\text { can collaborate }\end{array}$ & 郑刚2006 \\
\hline \multirow{5}{*}{$\begin{array}{l}\text { Managem } \\
\text { ent } \\
\text { innovation }\end{array}$} & A36 & $\begin{array}{l}\text { Concerned by the company's technology } \\
\text { platform and modular and standardized } \\
\text { documentation }\end{array}$ & Kogut et al 1992 \\
\hline & A37 & $\begin{array}{l}\text { The company's intellectual property rights } \\
\text { owned by regularly audit }\end{array}$ & Nonaka1994 \\
\hline & A38 & $\begin{array}{l}\text { Technical supervisor for intellectual property } \\
\text { management efforts }\end{array}$ & Teece1997 \\
\hline & A39 & $\begin{array}{l}\text { Product research and development equipment } \\
\text { utilization }\end{array}$ & 吴晓波2007 \\
\hline & $\mathrm{A} 40$ & $\begin{array}{l}\text { The degree of network file management } \\
\text { technology }\end{array}$ & Chesbrough2003 \\
\hline
\end{tabular}

Table .2: Article Related Assumptions

\begin{tabular}{|l|l|}
\hline \multicolumn{1}{|c|}{ Assumption } & Describe \\
\hline H1 & $\begin{array}{l}\text { Enterprise innovation culture and innovation strategy has positive } \\
\text { synergy }\end{array}$ \\
\hline H2 & Enterprise innovation culture and innovation have positive synergy \\
\hline H3 & Enterprise innovation culture and innovation have positive synergy \\
\hline H4 & $\begin{array}{l}\text { Enterprise culture of innovation and market innovation has a positive } \\
\text { synergy }\end{array}$ \\
\hline H5 & $\begin{array}{l}\text { Enterprise culture of innovation and management innovation has a } \\
\text { positive synergy }\end{array}$ \\
\hline H6 & $\begin{array}{l}\text { Enterprise innovation culture and organizational innovation has a } \\
\text { positive synergy }\end{array}$ \\
\hline
\end{tabular}


Journal of Business Studies - JBS Vol.13 Issue.2, December 2017

Table .5: The Reliability Test Results

\begin{tabular}{|l|l|l|l|}
\hline The variable name & Number of samples & Number & $\alpha$ coefficients \\
\hline Market innovation & 323 & 5 & 0.913 \\
\hline Organizational innovation & 323 & 5 & 0.808 \\
\hline System innovation & 323 & 6 & 0.873 \\
\hline Strategic innovation & 323 & 5 & 0.868 \\
\hline Technology innovation & 323 & 5 & 0.848 \\
\hline Innovation culture & 323 & 5 & 0.858 \\
\hline Management innovation & 323 & 5 & 0.865 \\
\hline
\end{tabular}

Table. 6: Factor Analysis Results

\begin{tabular}{|c|c|c|c|c|c|c|c|c|c|c|}
\hline \multirow{2}{*}{ Name } & \multirow{2}{*}{ Project } & \multicolumn{8}{|c|}{ Loading } & \multirow[t]{2}{*}{$\alpha$ coeffcient } \\
\hline & & F1 & F2 & F3 & F4 & F5 & F6 & F7 & F8 & \\
\hline \multirow{3}{*}{$\begin{array}{l}\text { F2 } \\
\text { Market Innovation }\end{array}$} & $\begin{array}{l}\text { A7Good eye of customer } \\
\text { needs }\end{array}$ & & .751 & & & & & & & \multirow{3}{*}{0.913} \\
\hline & $\begin{array}{l}\text { A8Accurate predictions of } \\
\text { future market }\end{array}$ & & .826 & & & & & & & \\
\hline & $\begin{array}{l}\text { A9Marketing department the } \\
\text { ability to set up business } \\
\text { model }\end{array}$ & & .809 & & & & & & & \\
\hline \multirow{3}{*}{$\begin{array}{l}\text { F3 } \\
\text { Organizational } \\
\text { Innovation }\end{array}$} & $\begin{array}{l}\text { A10Information and } \\
\text { knowledge between different } \\
\text { departments to communicate } \\
\text { normally help to promote } \\
\text { synergy }\end{array}$ & & & .652 & & & & & & \multirow{3}{*}{0.808} \\
\hline & $\begin{array}{l}\text { A11 degree of attention, the } \\
\text { higher the more senior } \\
\text { leadership and promoting } \\
\text { collaboration }\end{array}$ & & & .641 & & & & & & \\
\hline & $\begin{array}{l}\text { A12 conducive to innovative } \\
\text { organizational structure } \\
\text { should be flexible enough }\end{array}$ & & & .646 & & & & & & \\
\hline \multirow{5}{*}{ F4Innovation } & $\begin{array}{l}\text { A15 encourage the } \\
\text { development of innovative } \\
\text { learning and training system }\end{array}$ & & & & .916 & & & & & \multirow{5}{*}{0.873} \\
\hline & $\begin{array}{l}\text { A17 innovative fully } \\
\text { authorized staff }\end{array}$ & & & & .909 & & & & & \\
\hline & $\begin{array}{l}\text { A18 set up to promote the } \\
\text { exchange of information and } \\
\text { sharing of knowledge among } \\
\text { employees organizational } \\
\text { platform }\end{array}$ & & & & .912 & & & & & \\
\hline & $\begin{array}{l}\text { A19 companies provide } \\
\text { resources to support } \\
\text { innovation }\end{array}$ & & & & .914 & & & & & \\
\hline & $\begin{array}{l}\text { A20 enterprises to encourage } \\
\text { innovation }\end{array}$ & & & & .937 & & & & & \\
\hline \multirow{4}{*}{$\begin{array}{l}\text { F5Strategic } \\
\text { Innovation }\end{array}$} & $\begin{array}{l}\text { A21 corporate executives } \\
\text { have dedicated staff } \\
\text { responsible for the } \\
\text { development and } \\
\text { implementation of innovative } \\
\text { strategies }\end{array}$ & & & & & .914 & & & & \multirow{4}{*}{0.868} \\
\hline & $\begin{array}{l}\text { A22 corporate executives } \\
\text { clearly the degree of } \\
\text { innovation strategy }\end{array}$ & & & & & .903 & & & & \\
\hline & $\begin{array}{l}\text { A23 designed excellent vision } \\
\text { and continuous improvement }\end{array}$ & & & & & .908 & & & & \\
\hline & $\begin{array}{l}\text { A24 high-tech enterprise } \\
\text { investment efforts }\end{array}$ & & & & & .889 & & & & \\
\hline
\end{tabular}


Journal of Business Studies - JBS Vol.13 Issue.2, December 2017

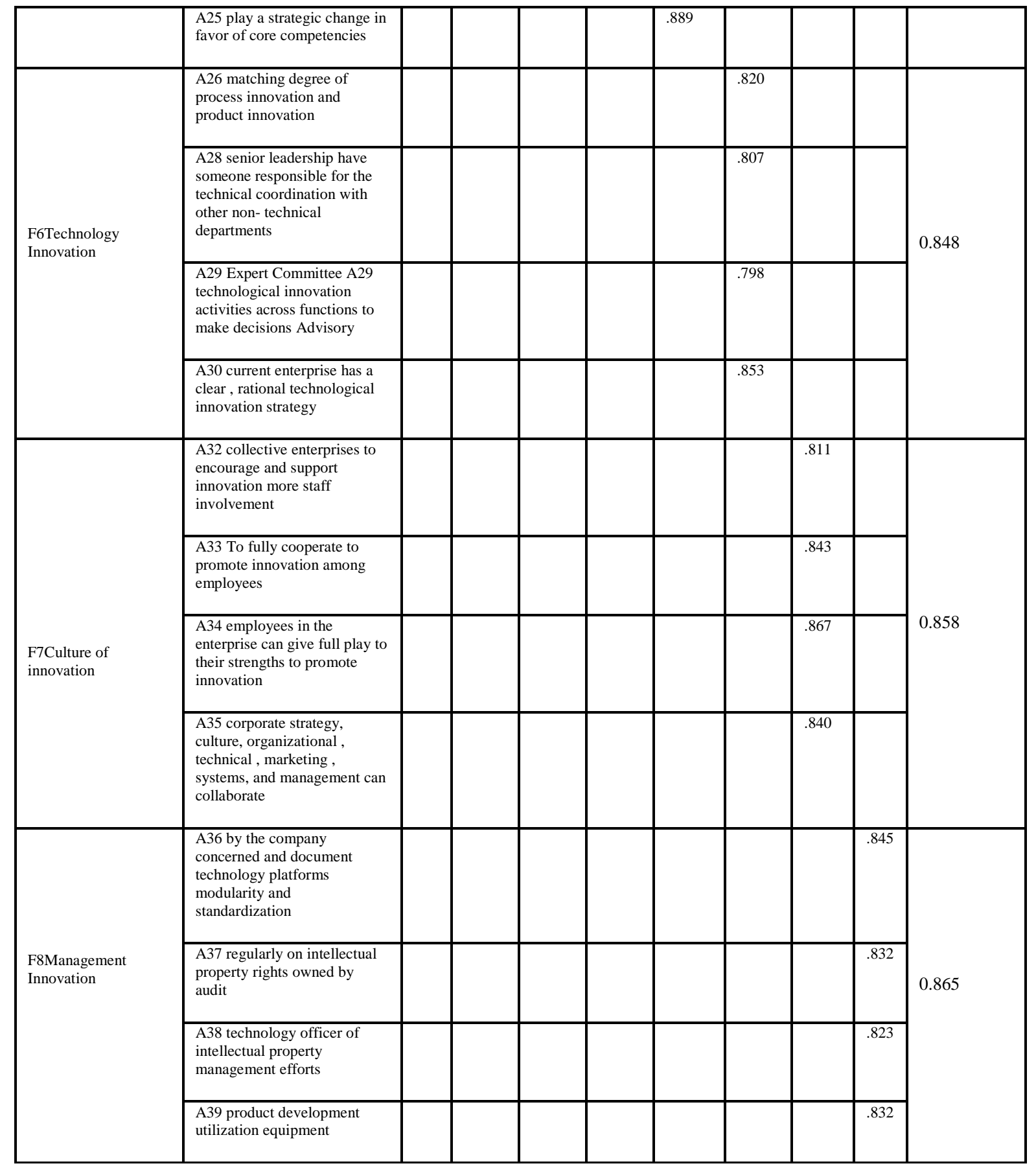

Table .8: Model fitting Coefficients and Hypothesis Testing

\begin{tabular}{|l|l|l|l|l|l|l|}
\hline Project & Estimate & S.E. & C.R. & P & Hypothesis & Assumptions \\
\hline whculture<-->zlstrategy & -.432 & .019 & -4.812 & $* * *$ & $\begin{array}{l}\text { Not } \\
\text { supported }\end{array}$ & H1 \\
\hline whculture<-->jsTech & .122 & .038 & 2.539 & $* * *$ & Supported & H2 \\
\hline whculture<-->zdsystem & .381 & .027 & 5.940 & $* * *$ & Supported & H3 \\
\hline whculture<-->scmarket & .263 & .022 & 5.589 & $* * *$ & Supported & H4 \\
\hline whculture<-->glmanagement & .154 & .029 & 3.273 & $* * *$ & Supported & H5 \\
\hline whculture<-->zzorganization & .192 & .025 & 3.35 & $* * *$ & Supported & H6 \\
\hline
\end{tabular}

